Spreckels' Sugar Refinery, volumes of the Official Gazette of the U. S. Patent Office.

Mr. Harrison D. Stratton, pamphlets on refrigeration.

Miss Wood, books on various subjects.

The executors of the estate of Mrs. W. H. Wahl, books, pamphlets, and maps from the library of the late William H. Wahl.

The U. S. Bureau of Standards, publications.

Mr. Joseph A. Arnold, Editor and Chief, Division of Publications, U. S. Department of Agriculture, has supplied the Library with copies of the current publications of the Department, and the Committee is indebted to him for the continuance of this courtesy.

\title{
DUPLICATES.
}

A number of duplicates have been received during the year from various sources, and the total stock at this time is 678 volumes. These will be used for exchange purposes, and the material so received will be added to the Library.

$$
\text { BINDING. }
$$

The total work done in the bindery was as follows:

Recent volumes of periodicals $\ldots \ldots \ldots \ldots \ldots \ldots \ldots \ldots \ldots 328 . \pm$ Rebound

Recent volumes of periodicals charged to Chemical Periodi-

cal Binding Fund ....................... 26

Old volumes $\ldots \ldots \ldots \ldots \ldots \ldots \ldots \ldots \ldots \ldots \ldots \ldots \ldots \ldots, 6_{3} \quad 27$

Books purchased with the income of the Moore Fund ..... 4 I

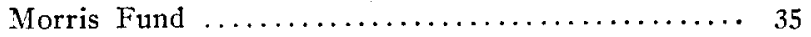

Potts Fund $\ldots \ldots \ldots \ldots \ldots \ldots \ldots \ldots \ldots \ldots \ldots \ldots \ldots \ldots \ldots$ I

$457 \quad 28$

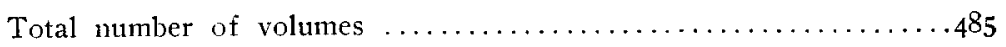

\section{REPORT OF THE COMMITTEE ON MUSEUMS} FOR THE FISCAL YEAR ENDING SEPTEMBER 30, 1914.

To the President and Members of The Franklin Institute:

The Committee on Museums begs to report progress for the year ended September 30, I9I4.

The following gifts have been received during the year and have been placed in charge of the Committee:

Model of J. P. Ross's Improved Reciprocating Engine, Lewisburg, Pa. Original adapted to blast furnaces and water works. Patented January 22, I856. Model to scale of threefourths inch to one foot. Gift of James C. Wobensmith, Esq.

Phantoscope, a motion-picture projecting machine, designed particularly for home use. Gift of Mr. C. Francis Jenkins, inventor. 
Atwater Kent Ignition System, a system of battery ignition for automobile engines. Model consists of "Unisparker," distributer and spark-plugs mounted on stand. Gift of Mr. A. Atwater Kent, inventor.

Bronze Bust of Matthias W. Baldwin, manager of the Institute, I827-1854; vice-president, $1855-1863$. Bust modelled by Herbert Adams, New York, I904, and cast by Aubry Brothers, New York; mounted on carved marble pedestal. Bequest of Mr. Francis T. Sully Darley.

Walnut Secretary Bookcase and Rug. Gifts of Miss Mary Thorn.

Several models have been received since the ending of the period this report covers, and mention of these will be included in the next report.

Respectfully submitted,

Alex. E. Outerbridge, Jr.,

Chairman.

Philadelphia, January I3, I9I5.

\section{REPORT OF THE COMMITTEE ON MEETINGS}

\section{FOR THE FISCAL YEAR ENDING SEPTEMBER 30, 1914.}

To the President and Members of The Franklin Institute:

During the year ending September 30 , I9I4, eight stated meetings were held.

At the May meeting the Elliott Cresson Medal was presented to Dr. Edgar F. Smith and to Dr. Orville Wright, two of the four scientists to whom this medal was awarded for distinguished achievement, the other two being Dr. Karl Ritter von Linde and Professor Dr. Josef Maria Eder. The presentations were made by President Walton Clark, and were followed by addresses from Dr. Smith and Dr. Wright.

Under arrangements made by your Committee, with the coöperation of the Secretary's office, papers were presented during the year as follows:

October 15, I9I3.

"The Revolving Cylinder Internal Combustion Motor." Emile Berliner, Washington, D. C.

November 19, I9I3.

"Producer Gas from Low-grade Fuels." R. H. Fernald, M.E., Ph.D., Consulting Engineer, U. S. Bureau of Mines; Whitney Professor of Dynamical Engineering, University of Pennsylvania, Philadelphia, Pa.

December 17, 1913.

“Petroleum and Its Derivatives." David T. Day, Ph.D., Department of the Interior, U. S. Geological Survey, Washington, D. C.

January 2I, I9I4.

"The Heat Received by the Earth from Stars and Planets." Ernest F. Nichols, Sc.D., LL.D., President, Dartmouth College, Hanover, N. H. 